\title{
PENDIDIKAN NILAI KEJUJURAN BERBASIS KELAS DI MADRASAH IBTIDAIYAH NEGERI 1 BANTUL YOGYAKARTA
}

\author{
Ichsan \\ Universitas Islam Negeri (UIN) Sunan Kalijaga Yogyakarta \\ ahasan_ty@yahoo.co.id
}

\begin{abstract}
This study specifically aims to find out the implementation of honesty values education in students through integration in learning and to find the actualization changes of students' honesty values after the implementation of honesty values education through integration in learning at MIN 1 Bantul. The research method used is action research. The research subjects were obtained by purposive sampling and snowball sampling. Data collection was done through observation, in-depth interviews, field notes, and documents, as well as questionnaired. The data were analyzed by using descriptive statistics which were presented in tables, percentages, and diagram. The results of changes that occur in students' attitudes and behaviors after learning development actions by integrating honesty values in learning Science, Mathematics, Social Sciences and Indonesian and developing madrasah culture, the actualization of honesty values increases.
\end{abstract}

Keywords: Education, Value, Honesty, Integration.

\begin{abstract}
Abstrak
Penelitian ini bertujuan menemukan kerterlaksanaan pendidikan nilai kejujuran pada diri siswa melalui integrasi dalam pembelajaran dan menemukan perubahan aktualisasi nilai kejujuran siswa setelah dilakukan tindakan pendidikan nilai kejujuran melalui integrasi dalam
\end{abstract}


pembelajaran di MIN 1 Bantul. Metode penelitian yang digunakan adalah penelitian tindakan. Subjek penelitian diperoleh secara purposivesampling dan snowball sampling. Pengumpulan data dengan teknik pengamatan, wawancara mendalam (in-depth interview), dan angket. Analisis data dengan deskriptif statistik yang disajikan dalam bentuk tabel, persentase, dan diagram. Hasil penelitian menunjukkan bahwa perubahan yang terjadi pada sikap dan perilaku siswa setelah dilakukan tindakan pembelajaran dengan mengitegrasikan nilai kejujuran dalam pembelajaran Sains atau IPA, Matematika, IPS, dan Bahasa Indonesia, aktualisasi nilai kejujuran meningkat.

Kata Kunci: Pendidikan, Nilai, Kejujuran, Integrasi.

\section{A. Pendahuluan}

Pendidikan nasional sebagaimana diamanatkan dalam Undang-undang Nomor 20 Tahun 2003 berfungsi mengembangkan kemampuan dan membentuk watak serta peradaban bangsa yang bermartabat dalam rangka mencerdaskan kehidupan bangsa, bertujuan untuk berkembangnya potensi peserta didik agar menjadi manusia yang beriman dan bertakwa kepada Tuhan Yang Maha Esa, berakhlak mulia, sehat, berilmu, cakap, kreatif, mandiri, dan menjadi warga negara yang demokratis serta bertanggung jawab.

Pendidikan nasional bertujuan untuk mengembangkan potensi peserta didik agar menjadi manusia yang beriman dan bertakwa kepada Tuhan Yang Maha Esa, berakhlak mulia, sehat, berilmu, cakap, kreatif, mandiri, dan menjadi warga negara yang demokratis serta bertanggung jawab. Dengan mencermati tujuan pendidikan nasional tersebut, maka pendidikan diharapkan mampu mewujudkan kemampuan yang utuh pada peserta didik, melipui kemampuan akademik atau modal intelektual, kemampuan sosial atau modal sosial, dan kemampuan moral atau modal moral. Ketiga modal tersebut merupakan modal maya, yang diperlukan setiap bangsa untuk bisa tetap tegap dan cerdas memasuki abad persaingan global, dan menjadi pemenang bukan menjadi pecundang. Jadi, modal maya adalah gabungan sinergik antara modal intelektual, modal sosial, dan modal moral.

Sekolah memang bukan sebuah tempat di mana seluruh persoalan bangsa dapat diselesaikan. Namun, sekolah menjanjikan 
banyak hal tentang perbaikan sebuah bangsa di masa depan. Fungsi pembentukan pribadi, terutama berkembangnya keutamaan intelektual, serta dampaknya bagi kehidupan sosial inilah yang membuat pendidikan nilai mendesak untuk dikembangkan sebgai strategi alternatif perbaikan kualitas bangsa. Sekolah memiliki peran besar dalam membentuk karakter bangsa.

Dunia sekolah erat kaitannya dengan peserta didik. Mereka terdiri dari guru, pelajar dan siswa, dan masih banyak yang lain. Dunia sekolah sering juga dikaitkan dengan kegiatan belajar mengajar. Kegiatan tersebut meliputi antara lain pemberian materi pelajaran, tugas, praktikum, dan ujian. Kegiatan tersebut menuntut peserta didik untuk berlaku adil dan jujur. Sikap adil dan jujur tersebut diperlukan karena akan menjadi modal dasar pembentukan pribadi mandiri dan sikap moral yang baik. Faktanya, di sekolah ada beberapa fenomena yang sering dijumpai misalnya menggunakan barang teman tanpa minta ijin terdahulu, menemukan barang tidak melaporkan, mencontek, dan lainnya, yang semua itu menggambarkan perilaku tidak jujur.

Mencontek merupakan sisi gelap kehidupan para pelajar dan siswa. Fenomena ini sering dihubungkan dengan para pelajar ataupun siswa karena sebagaian besar dari mereka pernah mencontek. Pernyataan ini didukung oleh hasil survey yang dilakukan oleh Muhammad W.T., dkk. terhadap 60 siswa SMA Negeri 10 Semarang pada tanggal 30 Juni 2010, menyebutkan bahwa 57 dari 60 subjek menyatakan mereka mencontek saat ujian, sedangkan 3 subjek menyatakan tidak pernah mencontek. Hasil penelitian ini juga menyebutkan bahwa 95\% mencontek saat ujian. Dari 57 responden yang mencontek, dapat dikelompokkan berdasarkan cara mereka mencontek, yaitu 51\% menyatakan mereka bertanya teman saat ujian, $26 \%$ mereka menyatakan dengan membawa contekan saat ujian, $12 \%$ menyatakan bahwa mereka memanfaatkan kelengahan petugas yang menjaga ujian, dan $11 \%$ menyatakan bahwa mereka mengirim jawaban lewat SMS atau memakai HP sebagai alat bantu mencontek (Muhammad 2010: 380-387).

Koesoema (2010: 17-23) menjelaskan berbagai sebab siswa mencontek antara lain: (1) perilaku tidak jujur, (2) adanya strukturdan kultur yang abai terhadap integtritas akademik, (3)ada 
ketakutan-ketakutan tertentu berkaitan denganprestasi akademik, (4) adanya kesempatan atau kemungkinan tidak ketahuan, (5) budaya mengatrol nilai, dan (6) tata peraturan yang membentuk struktur dan kultur sekolah.

Berdasarkan hasil wawancara dan pengamatan, fenomena jujuran siswa dalam pembelajaran sains, matematika, IPS, dan Bahasa Indonesia yang terjadi di Madrasah Ibtidaiyah Negeri (MIN) 1 Bantul dapat disajikan dalam tabel berikut.

Tabel 1

Pencapaian Kategori Nilai kejujuran Siswa Sebelum Tindakandalam pembelajaran Sains, matematika, IPS, dan Bahasa Indonesia.

\begin{tabular}{|c|c|c|c|c|c|c|c|c|}
\hline \multirow[t]{2}{*}{$\begin{array}{l}\text { Kriteria } \\
\text { Kejujuran }\end{array}$} & \multicolumn{2}{|c|}{$\begin{array}{c}\text { Pembelajaran } \\
\text { Sains }\end{array}$} & \multicolumn{2}{|c|}{$\begin{array}{c}\text { Pembelajaran } \\
\text { Matematika }\end{array}$} & \multicolumn{2}{|c|}{$\begin{array}{c}\text { Pembelajaran } \\
\text { IPS }\end{array}$} & \multicolumn{2}{|c|}{$\begin{array}{c}\text { Pembelajaran } \\
\text { Bahasa } \\
\text { Indonesai }\end{array}$} \\
\hline & $\mathrm{F}$ & $\%$ & $\mathrm{f}$ & $\%$ & $\mathrm{f}$ & $\%$ & $\mathrm{f}$ & $\%$ \\
\hline Sangat Tinggi & 5 & 19,23 & 6 & 23,08 & 10 & 38,46 & 7 & 26,92 \\
\hline Tinggi & 4 & 15,38 & 9 & 34,62 & 7 & 26,92 & 7 & 26,92 \\
\hline Rendah & 13 & 50,00 & 7 & 26,92 & 6 & 23,08 & 8 & 30,77 \\
\hline Sangat Rendah & 4 & 15,38 & 4 & 15,38 & 3 & 11,54 & 4 & 15,38 \\
\hline Jumlah & 26 & 99,99 & 26 & 100,00 & 26 & 100,00 & 26 & 100,00 \\
\hline
\end{tabular}

Dari Tabel 1 di atas dapat diketahui bahwa kejujuransiswa dalam pembelajaran Sains, kategori minimal rendah (sangat rendah+rendah) sebanyak $65,38 \%$, pada pembelajaran matematika, kategori minimal rendah sebanyak $42,3 \%$, pada pembelajaran IPS, kategori minimal rendah sebanyak $34,62 \%$, dan pada pembelajaran Bahasa Indonesia pencapaian tingkat kejujuran siswa kategori minimal tinggi sebanyak 46,15\%. Berdasarkan hal tersebut, perlu dicari upaya untuk meningkatkan kejujuransiswa melalui pembelajaran STAD untuk pembelajaran sains, Matematika, dan IPS. Adapun dalam pembelajaran bahasa Indonesia digunakan model pembelajaran LVEP.

Penelitian ini sangat perlu dilakukan mengingat guru selama ini dalam menanamkan nilai kejujuran tidak terintegrasi dalam pembelajaran dan baru sebatas pada rintisan kultur madrasah yang berupa kantin kejujuran, jabat tangan, dan kata-kata mutiara yang ditulis di kelas-kelas. Hal ini dilakukan untuk mendukung 
peningkatan guru $\mathrm{MI}$ dalam mengembangkan nilai kejujuran dalam pembelajaran Sains, matematika, IPS, dan Bahasa Indonesia. Penelitian ini merupakan penelitian tindakan (action research), karena penelitian ini bertujuan untuk meningkatkan kejujuran siswa. Creswell (2015: 180) menjelaskan bahwa penelitian tindakan merupakan penelitian terapan yang fokus pada tindakan tertentu. Penelitian ini menggunakan model Kemmis dan Taggart.

\section{B. Pembahasan}

\section{Kajian Teori}

\section{a. Nilai Kejujuran: Pengertian, Referensi, dan Fungsi Nilai}

Thomas Lickona dalam buku Educating for Character (1992) tentang komponen karakter baikyang terdiri dari: (1) pengetahuan moral (kesadaran moral, pengetahuan nilai moral, penentuan perspektif, pemikiran moral, pengambilan keputusan, dan pengetahuan pribadi), (2) perasaan moral (hati nurani, harga diri, empati, mencintai hal yang baik, kendali diri, dan kerendahan hati), (3) tindakan moral (kompetensi, keinginan, dan kebiasaan) (Lickona 2012: 84). Karakter yang baik terdiri atas mengetahui kebaikan, menginginkan kebaikan, dan melakukan kebaikan-kebiasaan pikiran, kebiasaan hati, kebiasaan perbuatan.

Dalam penjelasan di atas terlihat bahwa Thomas Lickona menguraikan tentang karakter dan moral. Moral dengan segala rincian yang dibuat oleh Lickona tersebut memiliki tahapan yaitu mengetahui apa itu karakter atau moral yang membuat berbagai nilai di dalamnya. Setelah mengetahui dengan baik, kemudian harus berusaha untuk merasakan dan menyadarinya. Kemudian pada tahap akhirnya adalah bagaimana melaksanakan karakter atau moral itu secara spontan. Kalau dapat melakukan moral action secara spontan berarti karakter itu telah mendarah-daging dan melekat pada dirinya. Hal ini nampaknya sejalan dengan urutan pembelajaran yang dimulai dari kognitif, afektif, dan psikomotor (mengetahui, memahami, dan melaksanakannya).

Diane Tillman (2004: xx-xxi) menyarankan urutan nilai yang diinternalisaikan kepada anak didik, yaitu: (1) kedamaian, (2) penghargaan, (3) cinta, (4) toleransi, (5) kebahagiaan, (6) tanggung jawab, (7) kerja sama, (8) kerendahan hati, (9) kejujuran, 
(10) kesederhanaan, (11) kebebasan, dan (12) persatuan. Dalam penjelasan Tillman, bahwa ururan tersebut tidak berlaku kaku tergantung kebutuhan dari masing-masing sekolah.

Sifat jujur seperti yang telah diuraikan dalam kutipan di atas merupakan salah satu inti dari komponen karakter. Menurut pengertian yang sering kita dengar, jujur adalah satunya ucapan dan perbuatan (Diane Tillman, 2004: 19). Pemahaman pengertian ini rasanya hanya benar kalau sebatas apa yang didengar dan dilihat. Pertanyaannya, apakah juga satu pikiran dalam otak dan satu pula dengan perasaan dalam hati seseorang, tentu pengertian jujur itu demikian luasnya. Jujur dideskripsikan sebagai perilaku yang didasarkan pada upaya menjadikan dirinya sebagai orang yang selalu dapat dipercaya dalam perkataan, tindakan, dan pekerjaan (Kementerian Pendidikan Nasional, 2010: 10). Deskripsi ini menekankan kepada upaya seseorang untuk dapat dipercaya. Kejujuran yang nampak bisa saja suatu kejujuran semu atau palsu yang seolah-olah jujur, padahal sebaliknya.

Jujur yang dalambahasa Inggris honest pun berasal dari bahasa Latin honestus (honorable) atau honos (honour), yang artinya kehormatan, kemurnian, atau reputasi (Agustian, 2009: 32). Kejujuran dapat diartikan sebagai sesuatu yang diyakini kebenarannya oleh seseorang, tetapi belum tentu dilaksanakan. Keyakinan akan kebenaran dari kejujuran itu sebagai perbuatannya sehari-hari yang menunjukkan moralnya. Mulyana menjelaskan perbedaan antara kejujuran dalam arti nilai dan kejujuran dalam arti moral. Nilai kejujuran sebagai nilai yang baik, bisa jadi berada pada posisi "kosong" dalam arti tak terwujudkan dalam tindakan. Beda dengan ketika kejujuran dinyatakan sebagai nilai moral. Ia sudah dimanifestasikan dalam tindakan sebagai adat kebiasaan seseorang. Dengan demikian, tema moral kejujuran seseorang akan secara langsung mendapat konsekuensi sosial baik atau buruk bagi si pelaku. Contoh kongkret yang diberikan oleh Mulyana untuk memperjelas perbedaan ini adalah ketika seseorang yang diduga memiliki kejujuran tetapi melakukan tindakan korupsi, maka dengan serta merta masyarakat menuduh dirinya sebagai orang yang tidak jujur (sanksi sebagai pertanggungjawaban sosial). Tetapi untuk kejujuran sebagai nilai sangat mungkin ia yakini baik dan penting bagi dirinya, namun 
tertangguhkan dulu untuk sementara waktu. Untuk itu, nilai dapat berada pada wilayah pra-moral yang sewaktu-waktu ditangguhkan oleh perilaku moral (Agustian, 2009: 18). Berkaitan dengan internalisasi nilai, terasa bahwa mungkin saja para siswa memahami kejujuran itu sebagai sesuatu nilai, tetapi untuk menjadikan nilai kejujuran itu sebagai sesuatu yang dapat dimanifestasikannya dalam kehidupan sehari-hari belum tentu sama dengan apa yang telah dipahami dan diyakininya. Namun demikian pemahaman dan keyakinan akan baiknya nilai kejujuran merupakan suatu awal untuk menjadikan kejujuran menjadi suatu moral yang wajib diamalkan.

Berbicara tentang konsep kejujuran, maka Islam merupakan agama yang sangat menekankan ajaran kejujuran apada umatnya. Hal ini dapat dilihat banyaknya kata jujur/benar (shiddiq) dalam Al-Qur'an dan hadis. Selain itu, terkenalnya Nabi Muhammad saw. dengan gelar al-Amin. Dalam Al-Qur'an, kata jujur disebut dengan kata shiddiq.

\section{b. Nilai-nilai Kejujuran yang Diinternalisasikan ke Peserta Didik}

Dalam buku Pengembangan Pendidikan Budaya dan Karakter Bangsa menjelaskan bahwa karakteristik nilai jujur untuk Sekolah Dasar adalah perilaku yang didasarkan pada upaya menjadikan dirinya sebagai orang yang selalu dapat dipercaya dalam perkataan, tindakan, dan pekerjaan. Nilai-nilai kejujuran yang dikembangkan untuk kelas atas berbeda dengan kelas bawah (Kementerian Pendidikan Nasional, 2010: 32). Dari hal tersebut di atas, dapat diketahui bahwa indikator kejujuran untuk kelas bawah berbeda dengan kelas atas. Pendidikan niai kejujurandi kelas bawah lebih menekankan kejujuran di dalam kelas, sedangkan kelas atas lebih menekankan kejujuran di sekolah dan di rumah. (Kementerian Pendidikan Nasional, 2010: 32).

Penelitian ini dilakukan di kelas bawah, yaitu pada kelas 3, nilai-nilai kejujuran yang diinternalisasikan meliputi: menjawab pertanyaan guru tentang sesuatu berdasarkan yang diketahui: (a) tidak mencontek pada saat mengerjakan ulangan, (b) tidak mencontoh teman ketika mengerjakan tugas, (c) berani mengakui kesalahan yang dilakukan, (d) mengerjakan ulangan tanpa melihat jawaban teman yang lain, (e) berani menyatakan tentang ketidaknyamanan suasana belajar di kelas,(f) meminta ijin atau menggunakan 
barang teman, (g) memberikan maaf kepada teman yangmembuat kesalahan, (h) meminta maaf kepada teman bila membuat kesalahan, (i) menyampaikan barang yang ditemukan kepada petugas, dan (j) disiplin.

\section{c. Urgensi Pendidikan Nilai Kejujuran di Madrasah Ibtidaiyah}

Banyak persoalan yang terjadi di negara kita saat ini antara lain disebabkan oleh semakin menipisnya kejujuran. Bahkan, dapat dikatakan bahwa kejujuran termasuk salah satu sendi utama yang dapat menopang tegaknya sendi-sendi kehidupan. Sebagai contoh, pejabat yang tidak jujur menyebabkan ia berbuat korupsi, pelajar yang tidak jujur menyebabkan ia suka mencontek, serta masih banyak lagi contoh yang akarnya berasal dari hilangnya sikap jujur (Aunillah, 2011: 47).

Pendidikan nilai kejujuran menjadi kebutuhan mendesak mengingat praktik-pratik ketidakjujuran sudah semakin akut menjangkiti bangsa ini di semua lapisan masyarakat. Pendidikan nilai kejujuran diharapkan mampu membangkitkan kesadaran bangsa ini untuk membangun pondasi kebangsaan yang kokoh. Thomas Lickona menyatakan bahwa salah satu tanda kehancuran bangsa adalah membudayanya ketidakjujuran (Fadillah, 2011: 92).

Pendidikan nilai memiliki tujuan dan misi yang sangat penting untuk menopang pembangunan karakter bangsa Indonesia pada umumnya dan keberhasilan pendidikan di sekolah pada khususnya. Dalam rangka ini, pemerintah Indonesia telah merumuskan kebijakan nasional pembangunan karakter bangsa. Dalam kebijakan Nasional Pembangunan Karakter Bangsa Tahun 2010-2025 ditegaskan bahawa karakter merupakan hasil keterpaduan empat bagian, yaitu olah hati, olah pikir, olah raga, dan olah rasa dan karsa. Olah hati terkait dengan perasaan, sikap, dan keyakinan/keimanan yang menjadi penyangga atau fondasi dalam membangun karakter seseorang. Olah pikir berkenaan dengan proses nalar guna mencari dan menggunakan pengetahuan kritis, kreatif, dan inovatif, sehingga mendukung terwujudnya karakter secara tepat dan terarah. Olah raga terkait dengan proses persepsi, kesiapan, peniruan, manipulasi, dan penciptaan aktivitas baru disertai sportivitas yang memberikan motivasi dan kesempatan untuk melatih seseorang dalam mewujudkan karakter 
secara kondusif. Sementara itu, olah rasa dan karsa berhubungan dengan kemauan dan kreativitas yang tercermin dalam kepedulian, pencitraan, dan penciptaan kebaruan yang merupakan upaya untuk merealisasikan karakter seseorang yang utuh(Pemerintah Republik Indonesia, 2010: 21). Mengingat kejujuran merupakan salah satu sikap yang penting di miliki oleh semua lapisan masyarakat, maka perlu bagi sekolah-sekolah dan madrasah untuk menanamkan sikap ini kepada pesesrta didik agar mereka memahami pentingnya sikap jujur sejak dini.

Menanamkan nilai-nilai kejujuran bagi peserta didik sejak dini tentu saja dapat dilakukan pada saat mereka masih duduk di sekolah dasar atau madrasah ibtidaiyah. Tekait hal ini, banyak pendapat yang menyatakan bahwa Sekolah Dasar atau Madrasah Ibtidaiyah menjadi wadah utama dalam pembentukan karakter (Aunillah, 2011: 48).

\section{d. Karakteristik Perkembangan Anak Usia Madrasah Ibtidaiyah}

Pemahaman karakteristik siswa Madrasah Ibtidaiyah dimaksudkan agar setiap guru pengajar tidak keliru dan sesuai dengan kebutuhan siswa. Oleh karena itu, memahami karakteristik siswa merupakan keharusan sebagai langkah awal ketika akan merancang perencanaan pembelajaran dan pelaksanaan pembelajaran. Anak usia Madrasah Ibtidaiyah (MI), yang dalam psikologi perkembangan disebut dengan istilah akhir masa kanak-kanak, dimulai ketika anak berusia enam tahun sampai kematangan seksual. Usia ini orang tua sering menyebut sebagai masa yang menyulitkan, usia tidak rapih, dan usia bertengkar. Para pendidik, usia ini disebut usia kritis dalam dorongan berprestasi. Sedang para ahli psikologi menyebutnya sebagai usia berkelompok, usia penyesuaian diri, usia kreatif dan usia bermain (Hurlock, 2014: 146-148). Usia siswa Madrasah Ibtidaiyah, yang dalam pendidikan berkisar 6-12 tahun merupakan masa sekolah, mereka sudah dianggap cukup matang untuk belajar dan sekolah (Djumhana, 2009: 18).

Menurut Havighurst, setiap tahap perkembangan memiliki tugas perkembangannya sendiri-sendiri. Tugas perkembangan adalah suatu tugas yang muncul pada periode tertentu dalam rentang kehidupan individu, yang apabila tugas itu dapat diselesaikan akan membawa kebahagiaan dan kesuksesan pada tahap berikutnya; 
tetapi apabila tidak dapat diselesaikan dengan baik atau gagal, akan menimbulkan ketidakbahagiaan pada diri individu yang bersangkutan, menimbulkan penolakan masyarakat, dan kesulitan-kesulitan dalam menyelesaikan tahap-tahap berikutnya. Tugas-tugas perkembangan ini berkaitan erat dengan sikap, perilaku, atau ketrampilan yang dimiliki seseorang, sesuai dengan fase perkembangannya. Tugastugas perkembangan anak usia MI adalah: (1) mempelajari keterampilan-keterampilan fisik yang diperlukan untuk permainan, (2) membangun sikap yang sehat mengenai dirinya sendiri sebagai makhluk yang tumbuh, (3) belajar menyesuaikan diri dengan temanteman sebaya, (4) belajar memainkan peran sesuai dengan jenis kelaminnya, (5) belajar ketrampilan dasar membaca, menulis, dan berhitung, (6) belajar mengembangkan pengertian-penertian yang diperlukan untuk kehidupan sehari-hari, (7) mengembangkan hati nurani, pengertian moral, dan tata nilai, (8) mengembangkan sikap yang positif terhadap kelompok sosial dan lembaga-lembaga, dan (9) mencapai kebebasan pribadi (Khoiruddin Bashori, 2003: 20-21).

\section{e. Faktor-faktor Pendorong Perilaku Ketidakjujuran Siswa}

Faktor yang dapat menjadi pendorong seseorang (siawa) untuk melakukan tindakan atau perilaku ketidakjujuran sebagai berikut. Menurut pendapat Sigmund Freud, orang melakukan tindakan ketidakjujuran karena ingin menyenangkan diri sendiri dan orang lain (William Crain, 2007: 408), menghindari kegagalan atau mengurangi tekanan (pleasure principle)(Alwilsol, 2007: 17). Adapun menurut Burt, ada tiga faktor yang berpengaruh pada tingkah laku manusia, yaitu faktor G (General), yakni dasar yang dibawa sejak lahir, faktor S (Specific) yang dibentuk oleh pendidikan dan faktor C (Common/Group) yang didapatkan dari pengaruh kelompok. Pengaruh kelompok memberikan kontribusi yang cukup besar dalam menentukan perilaku. Perilaku ketidakjujuran sering diakibatkan oleh pengaruh kelompok dimana orang cenderung berani melakukan karena melihat orang lain di kelompoknya juga melakukan. Perilaku mencontek mahasiswa misalnya muncul disebabkan oleh kesuksesan teman dalam mencontek. Misalnya tidak ketahuan oleh pengawas saat mencontek atau nilai yang diperoleh teman yang mencontek lebih tinggi akan menjadi dorongan bagi mahasiswa untuk mencontek. Atau, bisa juga berupa pengalamannya sendiri pernah mencontek 
tanpa ketahuan oleh pengawas (Kirana dan Sri Lestari, 2012: 179). Hal ini mengacu pada teori Behaviorisme John Broadus Watson tentang terbentuknya perilaku dan kebiasaan memandang manusia sebagai produk lingkungan (Sarlito W. Sarwono, 2008: 74).

Dari teori-teori motivasi, diketahui bahwa perilaku ketidakjujuran dapat terjadi apabila seseorang berada dalam kondisi tertekan (underpressure) atau apabila dorongan atau harapan untuk berprestasi jauh lebih besar daripada potensi yang dimiliki maka makin besar hasrat untuk mencontek. Dalam hal ini, perilaku mencontek tinggal menunggu kesempatan (Sondang P. Siagian, 2012: 167).

Dari uraian di atas dapat dikemukakan bahwa siswa melakukan perilaku ketidakjujuran antara lain dikarenakan ingin menyenangkan dirinya dan orang lain, menghindari tekanan, mengikuti lingkungan, dan hambatan aktualisasi.

\section{f. Pendidikan Nilai Kejujuran Berbasis Kelas}

Mengintegrasikan nilai-nilai kejujuran dalam kegiatan pembelajaran, kita perlu terlebih dahulu menyepakati makna pembelajaran itu sendiri. Hal ini perlu dilakukan karena pemaknaan yang berbeda tentang konsep pembelajaran yang digunakan dapat berpengaruh terhadap kualitas integrasi nilai kejujuran tersebut.

Pengintegrasian nilai-nilai kejujuran ke dalam kegiatan pembelajaran berarti memadukan, memasukkan, dan menerapkan nilai-nilai kejujuran dalam rangka membentuk, mengembangkan, dan membina tabiat atau kepribadian peserta didik yang jujur tatkala pembelajaran berlangsung (Ghufron, 2010: 17). Pendidikan nilai kejujuran yang diintegrasikan dalam berbagai bidang studi dapat memberikan pengalaman yang bermakna bagi peserta didik karena mereka memahami, menginternalisasikannya melalui proses pembelajaran. Dengan demikian, nilai-nilai tersebut dapat terserap secara alami lewat kegiatan sehari-hari (Zuchdi, Darmiyati, Zuhdan Kun Prasetya, 2010: 3). Pada dasarnya kegiatan pembelajaran, selain untuk menjadikan peserta didik menguasai kompetensi (materi) yang ditargetkan, juga dirancang untuk menjadikan peserta didik mengenal, menyadari, dan menginternalisasi nilai-nilai dan menjadi perilaku. Oleh karena itu, integrasi nilai-nilai kejujuran ke dalam kegiatan pembelajaran, sesungguhnya kegiatan tersebut ingin 
merealisasikan terhadap apa yang tertera dalam kurikulum yang berlaku di sekolah. Integrasi dapat dilakukan dalam substansi materi, pendekatan dan metode pembelajarn, serta model eveluasi yang dikembangkan (Triatmanto, 2010: 19-20). Pada prinsipnya semua mata pelajaran dapat digunakan sebagai alat untuk mengembangkan kejujuran peserta didik, namun dalam penelitian ini dipilih pada substansi materi dan metode atau pendekatan pembelajaran.

Integrasi nilai kejujuran dalam pendekatan atau metode pembelajaran digunakan pendekatan pembelajaran kooperatif tipe Student Teams Achievement Division (STAD) untuk pembelajaran IPA atau Sains, Matematika, IPS, dan Living Values Education Program (LVEP) untuk pembelajaran bahasa Indonesia.

\section{Hasil Penelitian}

\section{a. Integrasi Pendidikan Nilai Kejujuran dalam Pembelajaran}

1) Pembelajaran Sains dengan Pendekatan Pembelajaran Kooeperatif Model Student Teams Achievement Division (STAD)

Dalam penelitian ini, pengembangan nilai kejujuran dalam pembelajaran Sains diintegrasikan melalui pendekatan pembelajaran kooperatif model STAD, yang dalam pelaksanaanya dilakukan dengan tiga siklus. Proses pembelajaran sains dengan pendekatan Pembelajaran kooperatif model STADdapat digunakan untuk meningkatkan kejujuran siswa. Peningkatan kejujuran siswa berturutturut dari siklus I, II, dan III ditunjukkan pada tabel berikut.

Tabel 2

\section{Perbandingan Nilai Kejujuran Siswa Sebelum Tindakan} dengan Siklus I, II, dan III

\begin{tabular}{lllllllll}
\hline \multirow{2}{*}{$\begin{array}{c}\text { Kriteria } \\
\text { Kejujuran }\end{array}$} & \multicolumn{2}{c}{$\begin{array}{c}\text { Pra } \\
\text { Tindakan }\end{array}$} & \multicolumn{2}{c}{ Siklus I } & \multicolumn{2}{c}{ Siklus II } & \multicolumn{2}{c}{ Siklus III } \\
\cline { 2 - 10 } & $\mathrm{f}$ & $\%$ & $\mathrm{f}$ & $\%$ & $\mathrm{f}$ & $\%$ & $\mathrm{~F}$ & $\%$ \\
\hline Sangat Tinggi & 5 & 19,23 & 11 & 42,31 & 16 & 61,54 & 18 & 69,23 \\
\hline Tinggi & 4 & 15,38 & 8 & 30,77 & 4 & 15,384 & 5 & 19,23 \\
\hline Rendah & 13 & 50,00 & 4 & 15,38 & 4 & 15,384 & 3 & 11,54 \\
\hline Sangat Rendah & 4 & 15,38 & 3 & 11,54 & 2 & 7,692 & 0 & 0,00 \\
\hline Jumlah & 26 & 99,99 & 26 & 100,00 & 26 & 100,00 & 26 & 100,00 \\
\hline
\end{tabular}


Keterangan: \% dihitung dari jumlah siswa yang mencapai kriteria dibandingkan dengan jumlah seluruh siswa.

Dari tabel tersebut di atas dapat diketahui bahwa kejujuran siswa kategori minimal tinggi (tinggi+sangat tinggi)sebelumdilakukan tindakan sebesar 34, 62\% dan setelah dilakukan tindakan pada Siklus I sebesar 73,08\%, Siklus II sebesar 76,92\%, dan pada Siklus III sebesar $88,45 \%$. Hal ini menunjukkan ketika menjawab pertanyaaan guru, mengerjakan ulangan, mengerjakan tugas dan menggunakan barang milik teman ditunjukkan semakin baik. Begitu juga bila melakukan kesalahan anak mengakui kesalahan yang dilakukan, bahkan anak meminta maaf serta berani mengungkapkan ketidaknyamanan suasana belajar di kelas. Perbandingan pencapaian nilai kejujuran siswa kategori minimal tinggi pada Pra Tindakan, Siklus I, II, dan III dapat dilihat pada Gambar 1 berikut.

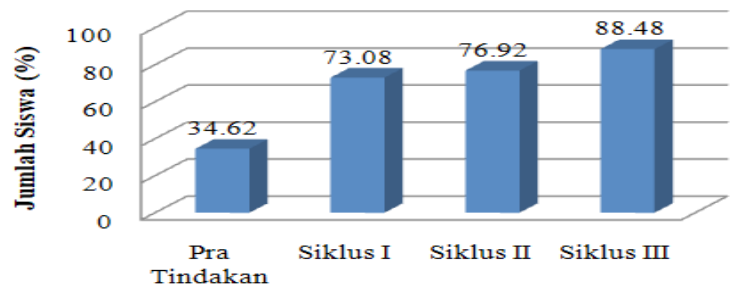

\section{Gambar 1 \\ Diagram Perbandingan Pencapaian Nilai Kejujuran Siswa Sebelum Pra Tindakan dan Setiap Siklusnya}

Dalam penelitian ini terdapat perbedaan kejujuran siswa antara penerapan pendekatan pembelajaran kooeratif model STAD danmetode konvensional pada pembelajaran sains, terbukti melalui hasil uji-t dua pihak menunjukkan bahwa nilai $t_{\text {hitung }}=8,448$ ternyata lebih besar dari $t_{\text {tabel }}=2,06$, dengan sig. $=0,000$; sig. $<0,05$ yang berarti ada perbedaan yang signifikan. Perbedaan mean sebesar $-3,808$ menunjukkan kejujuran siswa pembelajaran dengan STAD lebih baik dibandingkan dengan pembelajaran sebelumnya.

2) Pembelajaran Matematika dengan Pendekatan Pembelajaran Kooeperatif Model Student Teams Achievement Division (STAD)

Setelah dilakukan tindakan melalui pembelajaran Matematika dengan pendekatan pembelajaran kooperatif model STAD sebanyak tiga kali siklus, maka kategori kejujuran siswa mengalami peningkatan 
dari Pra Tindakan, Siklus I, Siklus II,dan Siklus III. Hal ini dapat dilihat pada Tabel 3 berikut.

Tabel 3

Perbandingan Nilai Kejujuran Siswa

Sebelum Tindakan dengan Siklus I, II, dan III

\begin{tabular}{lllllllll}
\hline \multirow{2}{*}{$\begin{array}{c}\text { Kriteria } \\
\text { Kejujuran }\end{array}$} & \multicolumn{2}{c}{$\begin{array}{c}\text { Pra } \\
\text { Tindakan }\end{array}$} & \multicolumn{2}{c}{ Siklus I } & \multicolumn{2}{c}{ Siklus II } & \multicolumn{2}{c}{ Siklus III } \\
\cline { 2 - 10 } & f & $\%$ & f & $\%$ & f & $\%$ & f & $\%$ \\
\hline Sangat Tinggi & 6 & 23,08 & 10 & 38,46 & 16 & 61,54 & 18 & 69,23 \\
\hline Tinggi & 9 & 34,62 & 7 & 26,92 & 3 & 11,54 & 4 & 15,385 \\
\hline Rendah & 7 & 26,92 & 6 & 23,08 & 5 & 19,23 & 4 & 15,385 \\
\hline Sangat Rendah & 4 & 15,38 & 3 & 11,54 & 2 & 7,69 & 0 & 0,00 \\
\hline Jumlah & 26 & 100,00 & 26 & 100,00 & 26 & 100,00 & 26 & 100,00 \\
\hline
\end{tabular}

Keterangan: \% dihitung dari jumlah siswa yang mencapai kriteria dibandingkan dengan jumlah seluruh siswa.

Dari Tabel 3 tersebut di atas dapat diketahui bahwa kejujuran siswa kategori minimal tinggi (tinggi+sangat tinggi) sebelum dilakukan tindakan sebesar 57, 69\% dan setelah dilakukan tindakan pada Siklus I sebesar 65,38\%, Siklus II sebesar 73,08\%, dan pada Siklus III sebesar $84,62 \%$. Hal ini menunjukkan ketika menjawab pertanyaaan guru, mengerjakan ulangan, mengerjakan tugas dan menggunakan barang milik teman ditunjukkan semakin baik. Begitu juga bila melakukan kesalahan anak mengakui kesalahan yang dilakukan, bahkan anak meminta maaf serta berani mengungkapkan ketidaknyamanan suasana belajar di kelas. Pebandingan pencapaian nilai kejujuran siswa kategori minimal tinggi (tinggi+sangat tinggi) pada Pra Tindakan, Siklus I, II dan III dapat dilihat pada Gambar 2 berikut.

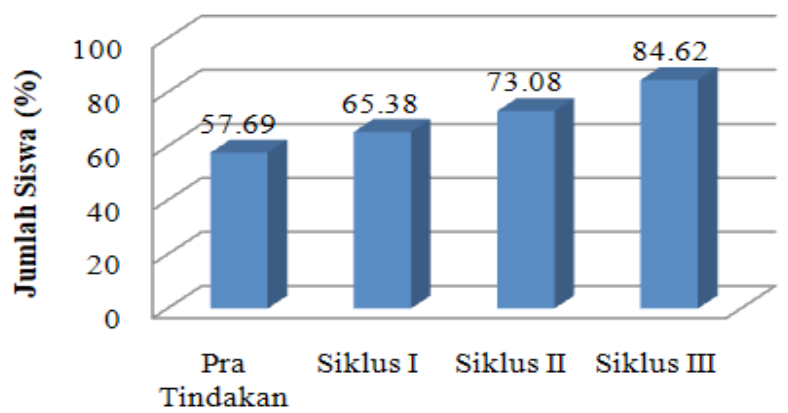

Gambar 2

Diagram Perbandingan Pencapaian Nilai Kejujuran Siswa Sebelum Pra Tindakan dan Setiap Siklusnya 
Penelitian ini menunjukkan adanya perbedaan kejujuran siswa antara Penerapan pendekatan pembelajaran kooeratif model STAD danmetode konvensional pada pembelajaran matematika, terbukti melalui hasil uji-t dua pihak menunjukkan bahwa nilai dengan $t{ }_{\text {hitung }}$ $=-16,013$ ternyata lebih besar dari $\mathrm{t}_{\text {tabel }}=2,06$, dengan sig. $=0,000$; sig. $<0,05$ yang berarti ada perbedaan yang signifikan. Perbedaan mean sebesar -4,346 menunjukkan kejujuran siswa pembelajaran dengan STAD lebih baik dibandingkan dengan pembelajaran sebelumnya.

3) Pembelajaran IPS dengan Pendekatan Pembelajaran Kooeperatif Model Student Teams Achievement Division (STAD)

Dalam penelitian ini pengembangan nilai kejujuran dalam pembelajaran IPS diintegrasikan melalui pendekatan pembelajaran kooperatif model STAD, yang dalam pelaksanaanya dilakukan dengan tiga siklus. Proses pembelajaran IPS dengan pendekatan Pembelajaran kooperatif model STADdapat digunakan untuk meningkatkan kejujuran siswa. Peningkatan kejujuran siswa berturutturut dari siklus I, II, dan III ditunjukkan dengan tabel berikut.

Tabel 4

Perbandingan Nilai Kejujuran Siswa

Sebelum Tindakan dengan Siklus I, II, dan III

\begin{tabular}{lllllllll}
\hline \multirow{2}{*}{$\begin{array}{c}\text { Kriteria } \\
\text { Kejujuran }\end{array}$} & \multicolumn{2}{c}{ Pra Tindakan } & \multicolumn{2}{c}{ Siklus I } & \multicolumn{2}{c}{ Siklus II } & \multicolumn{2}{c}{ Siklus III } \\
\cline { 2 - 10 } & F & $\%$ & f & $\%$ & f & $\%$ & f & $\%$ \\
\hline Sangat Tinggi & 10 & 38,46 & 13 & 50,00 & 16 & 61,54 & 19 & 7308 \\
\hline Tinggi & 7 & 26,92 & 5 & 19,23 & 3 & 11,54 & 4 & 15,38 \\
\hline Rendah & 6 & 23,08 & 5 & 19,23 & 5 & 19,23 & 3 & 11,54 \\
\hline Sangat Rendah & 3 & 11,54 & 3 & 11,54 & 2 & 7,69 & 0 & 0,00 \\
\hline Jumlah & 26 & 100,00 & 26 & 100,00 & 26 & 100,00 & 26 & 100,00 \\
\hline
\end{tabular}

Keterangan: \% dihitung dari jumlah siswa yang mencapai kriteria dibandingkan dengan jumlah seluruh siswa.

Dari Tabel 4 tersebut di atas dapat diketahui bahwa kejujuran siswa kategori minimal tinggi (tinggi+sangat tinggi) sebelum dilakukan tindakan sebesar $65,38 \%$ dan setelah dilakukan tindakan pada Siklus I sebesar 69,23\%, Siklus II sebesar 73,08\%, dan pada Siklus III sebesar $88,46 \%$. Perbandingan pencapaian nilai kejujuran siswa kategori minimal tinggi (tinggi+sangat tinggi) pada Pra Tindakan, Siklus I, II, dan III dapat dilihat pada Gambar 3 berikut. 


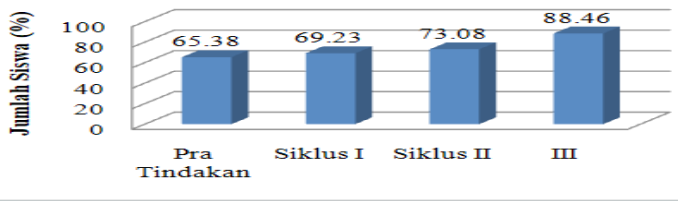

\section{Gambar 3}

Diagram Perbandingan Pencapaian Nilai Kejujuran Siswa Kategori Minimal Tinggi Sebelum Pra Tindakan dan Setiap Siklusnya

Terdapat perbedaan kejujuran siswa antara penerapan pendekatan pembelajaran kooeratif model STAD danmetode konvensional pada pembelajaran IPS, terbukti melalui hasil uji-t dua pihak menunjukkan bahwa nilai dengan $t_{\text {tabel }}=2,06$, dengan sig. $=0,000$; sig. $<0,05$ yang berarti ada perbedaan yang signifikan. Perbedaan mean sebesar $-4,115$ menunjukkan kejujuran siswa pembelajaran dengan STAD lebih baik dibandingkan dengan pembelajaran sebelumnya.

4) Pembelajaran Bahasa Indonesia dengan Model Living Values Education Program (LVEP)

Integrasi pendidikan nilai kejujuran dalam pembelajaran Bahasa Indonesia dengan metode LVEP dilakukan dengan langkahlangkah sebagai berikut.

a. Butir-butir refleksi. Mendefinisikan nilai kejujuran, menjelaskan tujuan pembelajaran yang ingin dicapai dan perubahan perilaku murid yang diharapkan.

b. Berimajinasi. Berimajinasi untuk membayangkan suasana kelas yang semua muridnya bersikap dan berperilaku sesuai dengan nilai kejujuran/nilai yang disepakati.

c. Tanya jawab. Tanya jawab tentang pengalaman mendengarkan atau menyimak cerita.

d. Bercerita. Murid mendengarkan cerita.

e. Diskusi. Diskusi kelompok untuk menyebutkan rangkaian peristiwayang terjadi, watak tokoh, dan menjelaskan amanat/pesan yang ada dalam cerita. Presentasi hasil diskusi tiap-tiap kelompok. Mengerjakan LKS.

f. Refleksi. Murid dan guru membuat kesimpulan berupa tulisan tentang poin-poin refleksi nilai kejujuran untuk dilaksanakan bersama-sama dalam kelas. 
Setelah dilakukan tindakan melalui pembelajaran Bahasa Indonesia dengan metode LVEPsebanyak tiga siklus, maka kategori kejujuran siswa mengalami peningkatan dari Pra Tindakan, Siklus I, Siklus II,dan Siklus III. Hal ini dapat dilihat pada Tabel 5 berikut.

Tabel 5

Perbandingan Nilai Kejujuran Siswa

Sebelum Tindakan dengan Siklus I, II, dan III

\begin{tabular}{lllllllll}
\hline \multirow{2}{*}{ Kriteria Kejujuran } & \multicolumn{2}{l}{ Pra Tindakan } & \multicolumn{2}{c}{ Siklus I } & \multicolumn{2}{c}{ Siklus II } & \multicolumn{2}{c}{ Siklus III } \\
\cline { 2 - 10 } & $\mathrm{F}$ & $\%$ & $\mathrm{~F}$ & $\%$ & $\mathrm{f}$ & $\%$ & $\mathrm{f}$ & $\%$ \\
\hline Sangat Tinggi & 7 & 26,92 & 11 & 42,31 & 15 & 57,69 & 19 & 73,08 \\
\hline Tinggi & 7 & 26,92 & 6 & 23,08 & 4 & 15,38 & 5 & 19,23 \\
\hline Rendah & 8 & 30,77 & 6 & 23,08 & 5 & 19,23 & 2 & 7,69 \\
\hline Sangat Rendah & 4 & 15,38 & 3 & 11,54 & 2 & 7,69 & 0 & 0,00 \\
\hline Jumlah & 26 & 100,00 & 26 & 100,00 & 26 & 100,00 & 26 & 100,00 \\
\hline
\end{tabular}

Keterangan: \% dihitung dari jumlah siswa yang mencapai kriteria dibandingkan dengan jumlah seluruh siswa.

Dari Tabel 5 tersebut di atas dapat diketahui bahwa kejujuran siswa kategori minimal tinggi (tinggi+sangat tinggi)sebelum dilakukan tindakan sebesar 53,85\% dan setelah dilakukan tindakan pada Siklus I sebesar 65,38\%, Siklus II sebesar 73,08\%, dan pada Siklus III sebesar 92,31\%. Hal ini menunjukkan ketika menjawabpertanyaaan guru, mengerjakan ulangan, mengerjakan tugas dan menggunakan barang milik teman ditunjukkan semakin baik. Begitu juga bila melakukan kesalahan anak mengakui kesalahan yang dilakukan, bahkan anak meminta maaf serta berani mengungkapkan ketidaknyamanan suasana belajar di kelas.

\section{b. Analisis Integrasi Nilai Kejujuran dalam Pembelajaran}

Hasil penelitian menunjukkan bahwa pengintegrasian pendidikan nilai kejujuran dalam pembelajaran Sains atau IPA, Matematika, IPS, dan Bahasa Indonesia membuat kejujuran murid meningkat. Pendidikan nilai kejujuran dalam penelitian ini sejalan dengan salah satu model pendidikan moral yang dikemukakan oleh Paul Suparno, yaitu model terintegrasi dalam semua bidang studi atau matapelajaran (Budiningsih, 2013: 2). Model ini memiliki kelebihan, bahwa semua guru ikut bertanggung jawab,dan pembelajaran tidak selalu bersifat informatif-kognitif, melainkan bersifat terapan padatiap bidang studi. Pendekatan yang digunakan 
dalam penelitian ini adalah pendekatan komprehensif. Sesuai dengan pendapat Kirscnbaum sebagaimana diungkapkan kembali oleh (Zuchdi, 2011: 198) bahwa pendekatan ini efektif untuk meningkatkan nilai-nilai karakter, karena pendekatan tunggal hanya mengatasi masalah secara parsial. Temuan ini juga sejalan dengan pendapat Ghufron (2010: 17) bahwa pengintegrasian nilai-nilai kejujuran ke dalam kegiatan pembelajaran berarti memadukan, memasukkan, dan menerapkan nilai-nilai kejujuran dalam rangka membentuk, mengembangkan, dan membina tabiat atau kepribadian peserta didik yang jujur tatkala pembelajaran berlangsung. Temuan ini juga sejalan dengan pendapat Lickona (2012: 123) bahwa pendekatan komprehensif memiliki kelebihan dapat menumbuhkan kehidupan moral di kelas. Temuan ini juga selaras dengan pendapat Aninditya Sri Nuhraheni (2012: xiv), bahwa metode pembelajaran yang digunakan pendidik untuk menyampaikan pelajaran bermuatan karakter adalah dengan pendidikan holistik. Pendidikan holistik berbasis karakter yaitu pembelajaran terpadu yang menyentuh semua aspek kebutuhan anak, saling terkait, tidak terkotak-kotak, dan dapat merefleksikan dimensi keterampilan dengan menampilkan tema-tema yang menarik dan kontektual. Model pendidikan ini merupakan teori sosial, emosi, kognitif, moral, dan spiritual. Penelitian ini juga sejalan dengan pendapat psikolog pendidikan, Spencer Kagan, bahwa jika kita ingin pendidikan nilai dapat masuk ke dalam situasi kehidupan nyata kinerja di luar kelas, maka kita harus menggunakan kelas sebagai "struktur belajar" yang memungkinkan murid untuk mempraktikkan kebaikan (Lickona, 2012b: 157).

Terjadinya peningkatan kualitas kejujuran murid yang berjalan seiring dengan peningkatan hasil belajar seperti dalam penelitian ini sesuai dengan laporan Benninga, bahwa sekolahsekolah yang melaksanakan pendidikan karakter dengan sungguhsungguh cenderung mencapai akademik yang lebih tinggi (Lickona, 2012b: 158). Hal ini sesuai dengan penjelasan Shriver dan Wiessberg, bahwa pengembangan ketrampilan sosial dan emosional sangat penting untuk pencapaian prestasi akademik (Zuchdi, dkk, 2011: 198). 


\section{Simpulan}

Pendidikan nilai kejujuranpada diri siswa berbasis kelas di MIN 1 Bantul dilakukan dengan mengintegrasikan nilai-nilai kejujuran dalam pembelajaran Sains atau IPA, Matematika, IPS dengan menggunakan pendekatan pembelajaran kooperatif tipe STAD, integrasi nilai-nilai kejujuran dalam pembelajaran Bahasa Indonesia menggunakan metode LVEP. Guru berhasil melaksanakan pembelajaran dengan pendekatan kooperatif tipe STAD dalam pembelajaran Sains, Matematika, dan IPS mulai dari pencapaian kategori rendah pada Siklus I, kategori tinggi pada siklus II, dan kategori sangat tinggi pada Siklus III. Demikian juga dalam pembelajaran Bahasa Indonesia, guru juga berhasil melaksanakan mulai dari pencapaian kategori rendah pada Siklus I, Kategori tinggi pada Siklus II, dan kategori sangat tinggi pada Siklus III.

Hasil perubahan yang terjadi pada sikap dan perilaku siswa setelah dilakukan tindakan pembelajaran dengan mengitegrasikan nilai kejujuran dalam pembelajaran Sains atau IPA, Matematika, IPS dan Bahasa Indonesia, aktualisasi nilai kejujuran meningkat. Peningkatan implementasi nilai kejujuran siswa pada pembelajaran Sains berturut-turut pada dari siklus I, II, dan III ditunjukkan dengan persentase jumlah siswa yang dapat mencapai kategori minimal tinggi (tinggi+sangat tinggi) sebesar 73,08\%; 76,92\%; dan $88,45 \%$. Peningkatan implementasi nilai kejujuran siswa pada pembelajaran Matematika berturut-turut pada dari siklus I, II, dan III ditunjukkan dengan persentase jumlah siswa yang dapat mencapai kategori minimal tinggi (tinggi+sangat tinggi) sebesar $65,38 \%$; 73,08\%; dan 84,62\%. Peningkatan implementasi nilai kejujuran siswa pada pembelajaran IPS berturut-turut pada dari siklus I, II, dan III ditunjukkan dengan persentase jumlah siswa yang dapat mencapai kategori minimal tinggi (tinggi+sangat tinggi) sebesar 69,23\%; 73,08\%; dan 88,46\%. Peningkatan implementasi nilai kejujuran siswa pada pembelajaran Bahasa Indonesia berturut-turut pada dari siklus I, II, dan III ditunjukkan dengan persentase jumlah siswa yang dapat mencapai kategori minimal tinggi (tinggi+sangat tinggi) sebesar 65,38\%; 73,08\%; dan $92,31 \%$. Meningkatnya sikap dan perilaku jujur siswa tersebut 
ditandai dengan siswa yang mencontek berkurang, menjawab pertanyaan guru berdasarkan yang diketahunya meningkat, sedikit siswa yang mencontoh dan melihat pekerjaan teman lainnya, menggunakan barang milik teman dengan minta ijin meningkat, serta terjadi peningkatan siswa dalam melaporkan barang yang ditemukan. 


\section{DAFTARPUSTAKA}

Agustian, Ari Ginajar. 2009. Bangkit Dengan 7 Budi Utama. Jakarta: PT Arga Publishing.

Aunillah, Nurla Isna. 2011. Panduan Menerapkan Pendidikan Karakter Di Sekolah. Yogyakarta: Laksana.

Budiningsih, C. Asri. 2013. Pembelajaran Moral Berpijak Pada Karakteristik Siswa Dan Budayanya. Jakarta: Rineka Cipta.

Creswell, John. 2015. Riset Pendidikan Perencanaan, Pelaksanaan, Dan Evaluasi Riset Kulalitatif Dan Kuantitatif. Yogyakarta: Pustaka Pelajar.

Djumhana, Nana. 2009. Pembelajaran Ilmu Pengetahuan Alam. Jakarta: Dirjen Pendidikan Islam Departemen Agama RI.

Fadillah. 2011. "Model Pembinaan Nilai Kejujuran Melalui Pendidikan Matematika Sebagai Upaya Meningkatkan Kecerdasan Moral Peserta Didik." Cakrawala Kependidikan 9(1). https://media.neliti.com/media/publications/218539model-pembinaan-nilai-kejujuran-melalui.pdf.

Ghufron, Anik. 2010. "Ntegrasi Nilai-Nilai Karakter Bangsa Pada Kegiatan Pembelajaran." Cakrawala Pendidikan 29: 13-24.

Hurlock, Elizabert B. 2014. Psikologi Perkembangan Suatu Pendekatan Sepanjang Rentang Kehidupan. Jakarta: Erlangga.

Kirana, Aulia dan Sri Lestar. 2012. "Bila Guru Melihat: Perilaku Jujur Dan Tidak Jujur Siswa SMA Berbasis Agama Pada Situasi Ujian.” In Prosiding Temu Ilmiah X Ikatan Psikologi Perkembnagan Indonesia, , 163-69.

Koesoema, Doni A. 2010. Mengembangkan Kultur Akademik Bagi Pembentukan Karakter Bangsa. Malang: Prodi Psikologi Fakultas Ilmu Pendidikan UNM.

Lickona, Thomas. 2012a. Caracter Matters: Bagaimana Membantu Anak Mengembangkan Penilaian Yang Baik, Integritas, Dan Kebajikan Penting Lainnya. Jakarta: Bumi Aksara.

___ 2012b. Educating for Character: Mendidik Untuk Membentuk Karakter. Jakarta: Bumi Aksara. 
Muhammad, dkk. 2010. Perilaku Mencontek Ditinjau Dari Perilaku Konformitas Dan Jenis Kelamin. Malang: Prodi Psikologi Fakultas Ilmu Pendidikan Universitas Negeri Malang.

Pemerintah Republik Indonesia. 2010. Kebijakan Nasional Pembangunan Karakter Bangsa Tahun 2010-2025. Jakarta: Pusat Kurikulum Balitbang Kemendiknas.

Triatmanto. 2010. "Tantangan Implementasi Pendidikan Karakter Di Sekolah." Cakrawala Pendidikan 29: 187-203.

Zuchdi, Darmiyati, Zuhdan Kun Prasetya, dan Muhsinatun Siasah Masruri. 2010. "Pengembangan Model Pendidikan Karakter Terintegrasi Dalam Pembelajaran Bidang Studi Di Sekolah Dasar." Cakrawala Pendidikan: 1-12.

Zuchdi, Darmiyati, dkk. 2011. Model Pendidikan Karakter Terintegrasi. Yogyakarta: UNY Press. 